\title{
EHMTI-0302. SUNCT syndrome, case report
}

\author{
A Kuqo ${ }^{1 *}$, J Kruja ${ }^{2}$ \\ From 4th European Headache and Migraine Trust International Congress: EHMTIC 2014 \\ Copenhagen, Denmark. 18-21 September 2014
}

\section{Introduction}

The short-lasting primary headache syndromes may be conveniently divided into those exhibiting marked autonomic activation and those without autonomic activation. The former group comprises chronic and episodic paroxysmal hemicrania, short-lasting unilateral neuralgiform headache with conjunctival injection and tearing (SUNCT syndrome) and cluster headache. SUNCT is relatively rare, with a recent study showing a prevalence of $6.6 / 100,000$ and an incidence of 1.2/100,000. The disorder has a male preponderance, with a sex ratio of 2:1.The typical age of onset is between 40 and 70 years, with a mean age of onset at 48 years.

\section{Methods}

We report the case of a 73 years old man, with a history of two months of right side retro-orbital severe stabbing headache attacks that last 70 seconds with a frequency of 5 to 7 attacks per hour. During the attacks he had ipsilateral conjuctival injection, periorbital and facial redness and sweating, eyelid edema, ptosis tearing and nasal congestion (video).

The patient was treated first with Gabapentin $600 \mathrm{mg} / \mathrm{d}$ but it was shown ineffective. We start the treatment with sodium valproate up to $1500 \mathrm{mg} / \mathrm{d}$ and after one month the patient had a significant reduction of attacks and their severity.

\section{Conclusion}

The most of drugs used in treatment of primary headaches are ineffective in the treatment of SUNCT syndrome. Sodium valproate is B recommendation of AAN, and may be good choice in treatment of this syndrome.

No conflict of interest.
Authors' details

${ }^{1}$ Neurology, UHC Mother Teresa, Tirana, Albania. ${ }^{2}$ Neurology, University of Medicine, Tirana, Albania.

Published: 18 September 2014

doi:10.1186/1129-2377-15-S1-C33

Cite this article as: Kuqo and Kruja: EHMTI-0302. SUNCT syndrome, case report. The Journal of Headache and Pain 2014 15(Suppl 1):C33.

\section{SpringerOpen ${ }^{\odot}$}

(c) 2014 Kuqo and Kruja; licensee Springer. This is an Open Access article distributed under the terms of the Creative Commons Attribution License (http://creativecommons.org/licenses/by/2.0), which permits unrestricted use, distribution, and reproduction in any medium, provided the original work is properly cited.

Submit your manuscript to a SpringerOpen ${ }^{\circ}$ journal and benefit from:

- Convenient online submission

- Rigorous peer review

- Immediate publication on acceptance

- Open access: articles freely available online

- High visibility within the field

- Retaining the copyright to your article

Submit your next manuscript at $>$ springeropen.com 